\title{
C5a receptor (CD88) promotes motility and invasiveness of gastric cancer by activating RhoA
}

\author{
Takayoshi Kaida $^{1}$, Hidetoshi Nitta ${ }^{1}$, Yuki Kitano ${ }^{1}$, Kensuke Yamamura ${ }^{1}$, Kota Arima ${ }^{1}$, \\ Daisuke Izumi ${ }^{1}$, Takaaki Higashi ${ }^{1}$, Junji Kurashige ${ }^{1}$, Katsunori Imai ${ }^{1}$, Hiromitsu \\ Hayashi $^{1}$, Masaaki Iwatsuki ${ }^{1}$, Takatsugu Ishimoto ${ }^{1}$, Daisuke Hashimoto ${ }^{1}$, Yoichi \\ Yamashita $^{1}$, Akira Chikamoto${ }^{1}$, Takahisa Imanura ${ }^{2}$, Takatoshi Ishiko ${ }^{1}$, Toru \\ Beppu $^{1}$, Hideo Baba ${ }^{1}$ \\ ${ }^{1}$ Department of Gastroenterological Surgery, Graduate School of Life Sciences, Kumamoto University, Kumamoto, Japan \\ ${ }^{2}$ Department of Molecular Pathology, Graduate School of Life Sciences, Kumamoto University, Kumamoto, Japan \\ Correspondence to: Hideo Baba, email: hdobaba@kumamoto-u.ac.jp \\ Keywords: C5a receptor, CD88, RhoA, gastric cancer \\ Abbreviations: C5aR, C5a receptor; GC, Gastric cancer; rC5a, recombinant human complement component C5a; GDP, \\ guanosine diphosphate; GTP, guanosine triphosphate \\ Received: March 14, $2016 \quad$ Accepted: October 01, $2016 \quad$ Published: October 14, 2016
}

\section{ABSTRACT}

Purpose: Anaphylatoxin $\mathrm{C5a}$ is a strong chemoattractant of the complement system that binds the $\mathrm{C5a}$ receptor ( $\mathrm{C5aR}$ ). The expression of $\mathrm{C5} \mathrm{aR}$ is associated with poor prognosis in several cancers. However, the role of $\mathrm{C5aR}$ in gastric cancer (GC) is unknown. The aim of this study was to examine the role of C5aR on GC cell motility and invasion.

Experimental Design: The mechanism of invasion via C5aR was assessed by analyzing cytoskeletal rearrangement and RhoA activity after C5a treatment. Moreover, we investigated the relationship between C5aR expression and the prognosis of GC patients.

Results: Two human GC cell lines (MKN1 and MKN7) had high C5aR expression. An invasion assay revealed that $\mathrm{C5}$ a stimulation promoted the invasive ability of MKN1 and MKN7 cells and that this was suppressed by knockdown of C5aR using siRNA or a C5aR-antagonist. Moreover, overexpression of C5aR in GC cells enhanced the conversion of RhoA-guanosine diphosphate (RhoA-GDP) to RhoA-guanosine triphosphate (RhoA-GTP) after C5a stimulation and caused morphological changes, including increased expression of stress fibers and filopodia. Examination of tumor specimens from 100 patients with GC revealed that high C5aR expression (35 of 100 samples, $35.0 \%$ ) was associated with increased invasion depth, vascular invasion and advanced stage. The 5-year overall survival of patients with high or low C5aR expression was $58.2 \%$ and $88.5 \%$, respectively $(p=0.008)$.

Conclusions: This study is the first to demonstrate that C5aR promotes GC cell invasion by activating RhoA and is associated with a poor prognosis in GC patients. Therefore, this study provides a biomarker for GC patients who require an advanced therapeutic strategy.

\section{INTRODUCTION}

Gastric cancer (GC) is the third leading cause of cancer related death worldwide [1]. Despite advancements in our diagnostic and surgical capabilities and the discovery of new anti-cancer drugs for GC [1, 2], invasion and metastasis of cancer cells are still significant riskfactors for GC [3]. GC is associated with deep invasion into tissue and with lymphatic, vascular and peritoneal metastasis. The 5-year survival rate is approximately 
$5-20 \%$ in patients with advanced or metastatic GC [3, 4]. Despite several oncogenes and oncoproteins, such as human epidermal growth factor receptor 2, ras homolog gene family member A (RhoA), CD44v and E-cadherin, being associated with the proliferative and invasive ability of GC cells [5-9], only trastuzumab, which targets human epidermal growth factor receptor 2, is currently used clinically to treat advanced GC. Moreover, as few as $20-30 \%$ of all patients treated with trastuzumab have a clinical benefit [4, 10]. Therefore, new molecular targets are required that regulate the growth, invasive and metastatic ability of GC cells.

Anaphylatoxin $\mathrm{C} 5 \mathrm{a}$ is a strong chemoattractant and an important factor of the complement system [11, 12]. The $\mathrm{C} 5 \mathrm{a}$ receptor $(\mathrm{C} 5 \mathrm{aR})$ is a $\mathrm{G}$-protein coupled receptor expressed by leukocytes [13]. C5a promotes leukocyte migration and their production of radical oxygen species by binding to the $\mathrm{C} 5 \mathrm{aR}$ expressed on their cellular membranes, resulting in the initiation of inflammation $[13,14]$. We previously reported that several solid cancer cells also express C5aR on their cellular membrane and that the $\mathrm{C} 5 \mathrm{a}-\mathrm{C} 5 \mathrm{aR}$ axis promotes the invasiveness of cholangiocarcinoma by inducing actin reorganization and production of matrix metalloproteases [15]. It was also reported that $\mathrm{C} 5 \mathrm{aR}$ expression in non-small lung cancer, breast cancer and ovarian cancer was associated with a poor prognosis [16-18]. However, the role of C5aR in GC is still mostly unknown. Here, we investigated the role of $\mathrm{C} 5 \mathrm{aR}$ on the motility and invasive ability of GC cells in vitro. Moreover, we analyzed the relationship between C5aR-expression and the prognosis of GC patients.

\section{RESULTS}

\section{Expression of $\mathrm{C5aR}$ in gastric cancer cell lines}

We firstly investigated the expression of $\mathrm{C} 5 \mathrm{aR}$ and C5a-like receptor 2 (C5L2, a second C5aR) in eight human GC cell lines. MKN1 and MKN7 cells had highexpression of C5aR and C5L2 (Figure 1A, Supplementary Figure S1). Next, we examined the growth ability of MKN1 and MKN7 cells when recombinant human complement component $\mathrm{C} 5 \mathrm{a}$ (rC5a) was used to stimulate the cells C5aRs. The growth of MKN1 and MKN7 cells was not increased by rC5aR (Figure $1 \mathrm{~B}$ and $1 \mathrm{C}$ ).

\section{C5aR stimulation enhanced the invasiveness of cells with high-expression of C5aR}

To analyze the invasive ability of cancer cells, with or without high $\mathrm{C5aR}$ expression, cells were treated with $\mathrm{rC5} \mathrm{a}$ and a Matrigel assay was performed. The invasiveness of MKN1 cells was enhanced 2.02-fold and 2.52-fold after treatment with $10 \mathrm{nM}$ and $100 \mathrm{nM}$ of rC5a, respectively, and the invasiveness of MKN7 cells was enhanced 1.93-fold and 2.28-fold, respectively (Figure 2A-2C). However, rC5a stimulation failed to increase the invasive ability of AGS cells that do not express C5aR (Figure 2D). Knockdown of C5aR-expression with C5aR siRNAs decreased the invasive ability of MKN1 and MKN7 cells (Figure 2E-2H). The C5aR antagonist W-54011 also suppressed the invasive ability of MKN1 and MKN7 cells by approximately $0.2-0.5$ fold (Figure 2I and 2J). There was not significant difference in the growth ability of MKN1 and MKN7 cells with the knockdown of C5aR-expression using two different siRNAs of C5aR (Supplementary Figure S2A).

\section{C5aR stimulation enhanced the invasive ability and motility of C5aR overexpressing NUGC3 cells}

To further analyze the mechanism of the C5a to C5aR signal in human cancer cells, we overexpressed C5aR in C5aR-negative NUGC3 cells (Figure 1A). Flow cytometry using a C5aR-antibody confirmed C5aR expression on NUGC3/C5aR cells but not on NUGC3/ mock cells (Figure 3A). The number of invasive NUGC3/ C5aR cells was enhanced 2.62-fold after stimulation with $10 \mathrm{nM}$ of rC5a (Figure 3B) and this was suppressed by W-54011 (Figure 3C). In addition, using real-time imaging, we evaluated the motility of NUGC3/C5aR cells after stimulating them with rC5a. Real-time imaging revealed that $10 \mathrm{nM}$ of $\mathrm{rC} 5 \mathrm{a}$ enhanced the total distance that the NUGC3/C5aR cells moved in Matrigel (Figure $3 \mathrm{D}$ and $3 \mathrm{E}$ ) and that $\mathrm{W}-54011$ suppressed the mobility of NUGC3/C5aR cells (Figure 3F and 3G). These results indicate that the $\mathrm{C} 5 \mathrm{a}-\mathrm{C} 5 \mathrm{aR}$ signal enhances the invasion and mobility of GC cells in vitro.

\section{C5a-C5aR signal enhances RhoA-GTP production and changes the morphology of C5aR-expressing NUGC3 cells}

The morphologic change of cancer cells after rC5a stimulation was analyzed by immunofluorescence staining for F-actin. The majority of NUGC3/C5aR cells clearly showed strong filopodia after 15 minutes and strong stress fibers after 30 minutes of rC5a treatment (Figure 4A). Because activated RhoA stimulates the appearance of stress fibers and focal adhesions in quiescent cells and induces a change in cellular shape, [19-22] we hypothesized that the enhanced invasive ability following C5a stimulation was associated with RhoA activity. To test this, a Rho GTPase activity assay was performed. A significant conversion from RhoA-GDP to RhoA-GTP in NUGC3/C5aR cells was detected 15 and 30 minutes after rC5a treatment (Figure 4B). However, NUGC3/mock cells did not show any change in actin cytoskeleton or conversion of RhoA-GDP to RhoA-GTP after stimulation with $\mathrm{rC} 5 \mathrm{a}$. These results suggest that $\mathrm{C} 5 \mathrm{a}-\mathrm{C} 5 \mathrm{aR}$ signaling enhances the conversion of RhoA-GDP to RhoA-GTP and causes morphological changes of gastric cancer cells. 
A

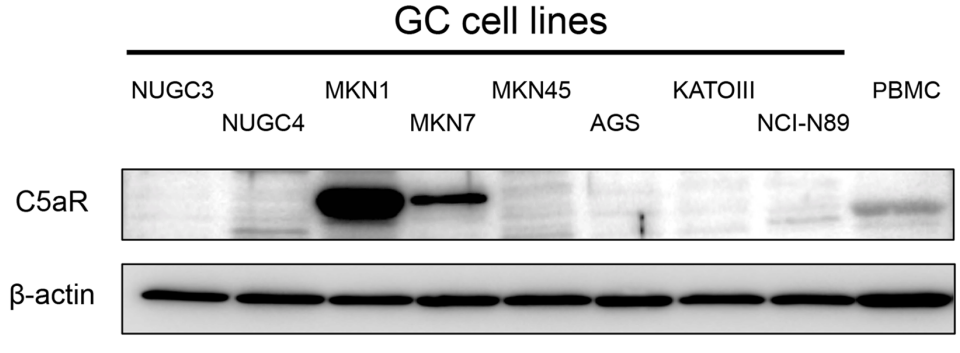

B

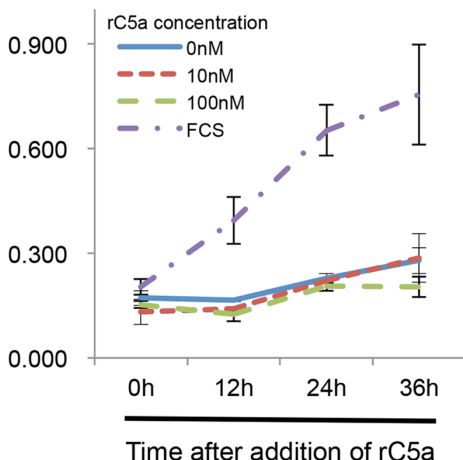

C

MKN7

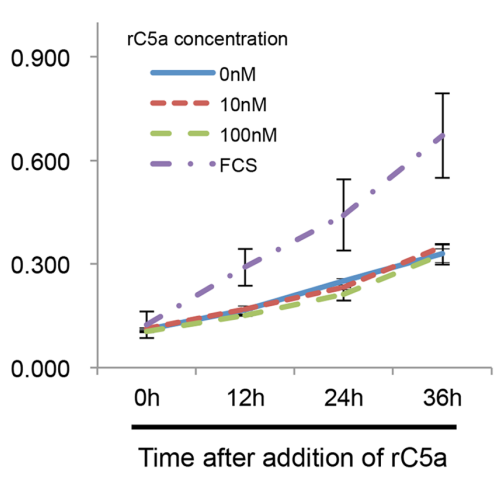

Figure 1: C5aR-expression in gastric cancer cell lines. A., Western blots demonstrating the level of C5aR-expression in gastric cancer cell lines. B and C., growth assays using Cell Counting Kit-8 showing the growth of C5aR positive and negative gastric cancer cells following stimulating with rC5a. C5aR: C5a receptor, PBMC: peripheral blood mononuclear cell, rC5a: recombinant C5a, GC: gastric cancer.

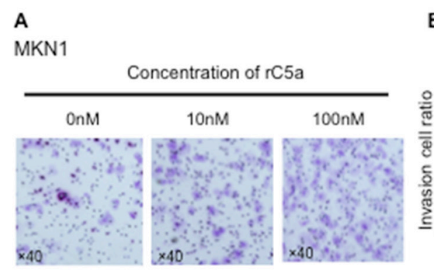

B $\quad$ MKN1

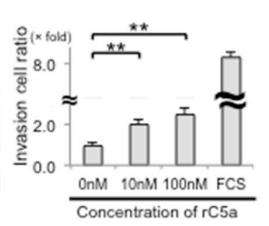

MKN7

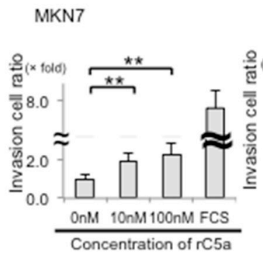

D

AGS
E
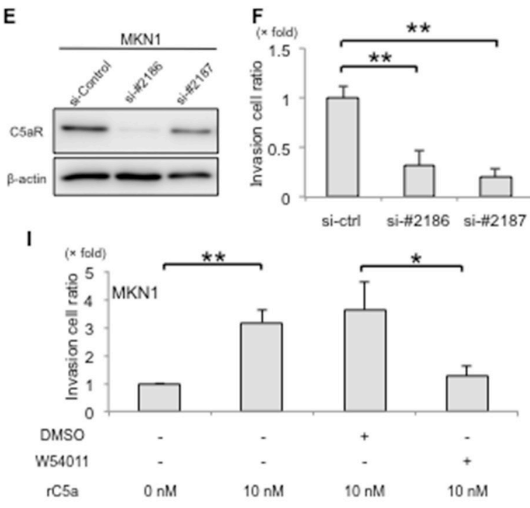

G

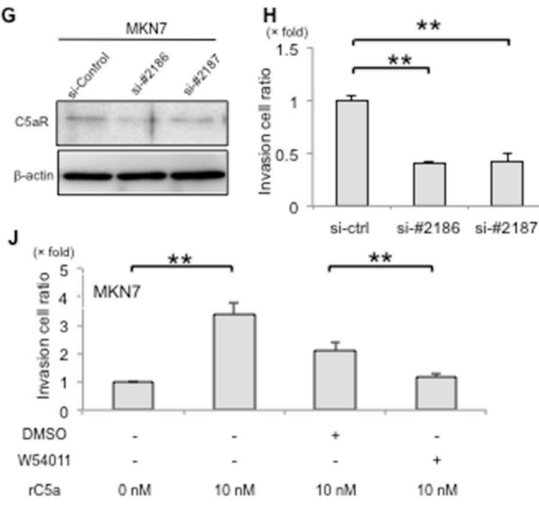

Figure 2: C5aR-stimulation with rC5a promotes invasion of gastric cancer cells. A., lower surfaces of an invasion membrane when MKN1 cells were assayed for invasion. B and C., rC5a significantly enhanced the invasive ability of MKN1 and MKN7 cells. D., rC5a did not enhance the invasive ability of AGS cells. E-H., suppression of C5aR-expression using two kinds of siRNA significantly decreased the invasive ability of MKN1 and MKN7 cells. I and J., W-54011, a C5aR-antagonist, significantly suppressed the invasive ability of MKN1 and MKN7 cells. C5aR, C5a receptor; rC5a, recombinant C5a; DMSO, Dimethyl sulfoxide; W-54011, C5aR-antagonist; $* \mathrm{p}<0.05 ; *{ }^{*}<0.01$. NS, not significant. 

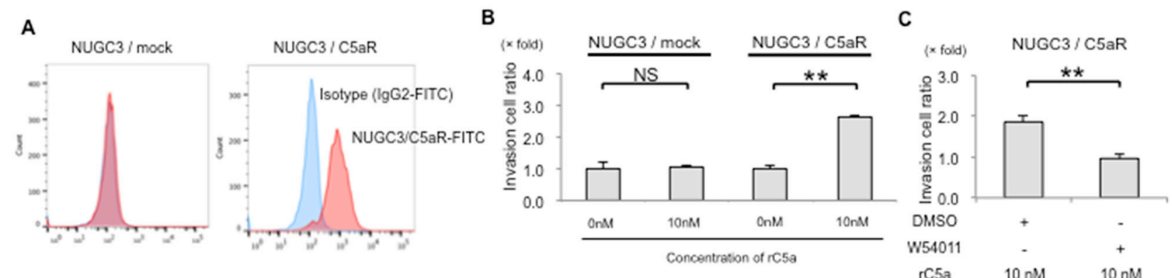
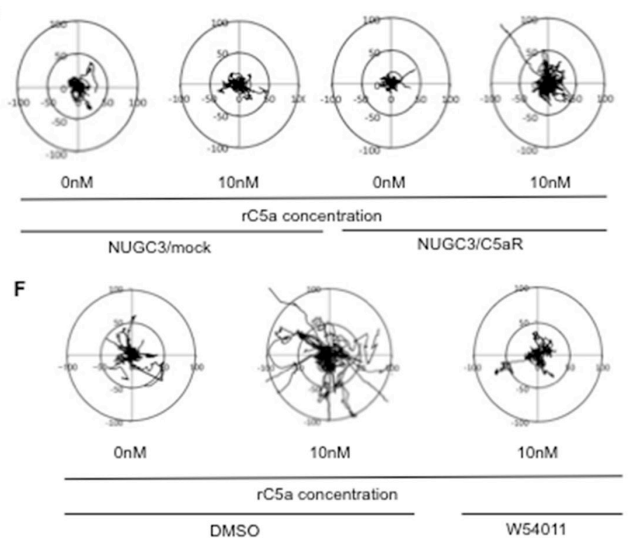

$\mathrm{E}$
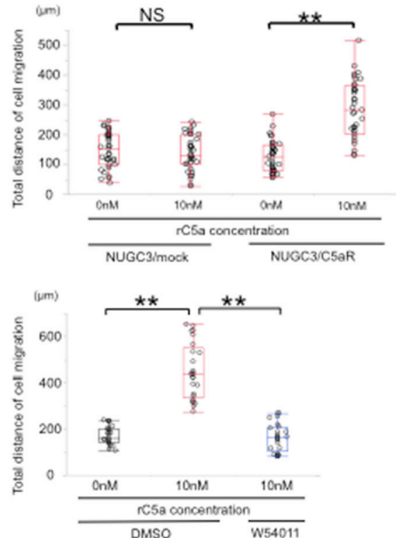

Figure 3: C5aR stimulation enhanced the invasive ability and motility of NUGC3 cell with C5aR-overexpression. A., Flow cytometry showed that C5aR proteins were overexpressed in the cellular membrane of NUGC3/C5aR cells. B., rC5a significantly promotes the invasive ability of NUGC3/C5aR cells, but did not significantly promote the invasive ability of NUGC3/mock cells. $\mathbf{C}$., W-54011 significantly decreased the invasive ability of NUGC3/C5aR cells. D and E., rC5a significantly promotes the mobility and the total distance of cell migration of NUGC3/C5aR cells but did not significantly promote the mobility of NUGC3/mock cells. F and G., W-54011 significantly decreased the mobility of NUGC3/C5aR cells. C5aR, C5a receptor; rC5a, recombinant C5a; DMSO, Dimethyl sulfoxide; W-54011, C5aR-antagonist; **p<0.01. NS, not significant.
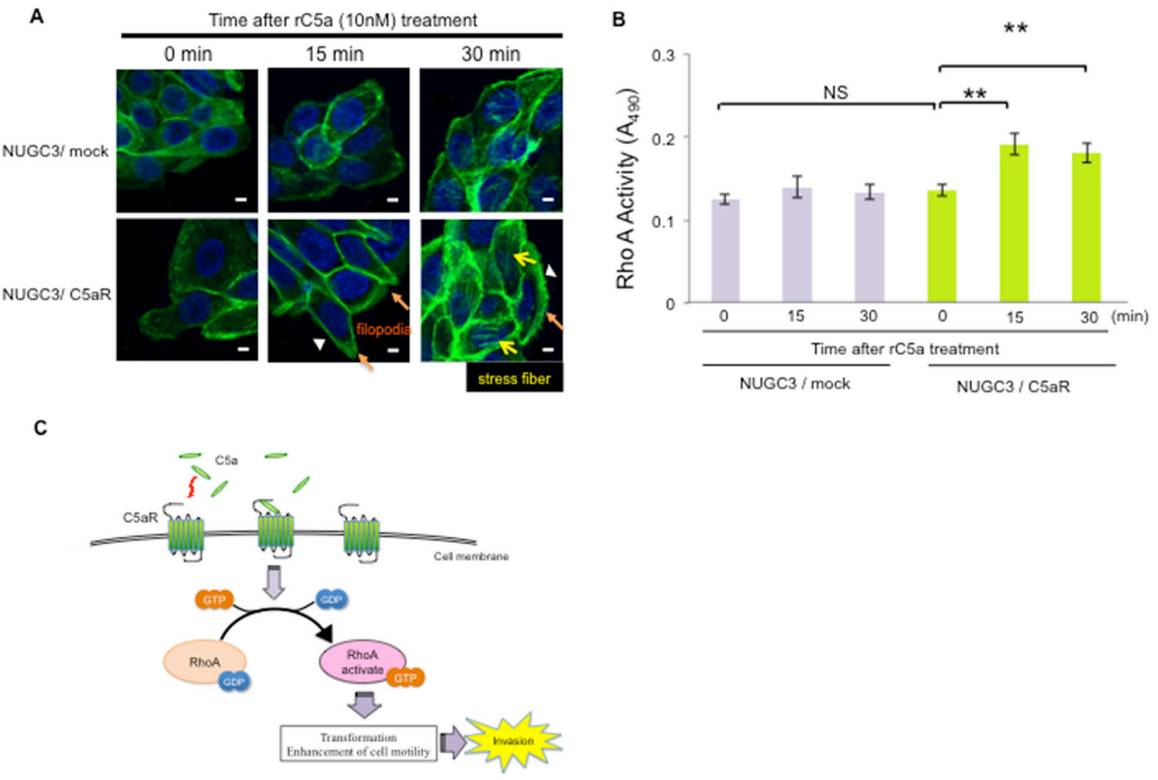

Figure 4: C5a-C5aR signaling enhances the production of RhoA-GTP and changes the cellular morphology of C5aRexpressing NUGC3 cells. A., NUGC3/C5aR and NUGC3/mock cells were incubated with $\mathrm{rC} 5 \mathrm{a}(10 \mathrm{nM})$ and fixed at the indicated times. F-actin was visualized by immunofluorescence staining with Alexa 488-conjugated phalloidin. Scale bars, $10 \mu \mathrm{m}$. Orange and yellow arrows and arrowheads indicate filopodia, stress fibers and membrane ruffling, respectively. B., analysis of the activation of RhoA using a G-LISA on the lysates of NUGC3/C5aR and NUGC3/mock cells were extracted at the indicated times after rC5a treatment. C., diagram of C5a-C5aR signaling via the RhoA pathway in gastric cancer cells. C5aR, C5a receptor; rC5a, recombinant C5a; GDP, guanosine diphosphate; GTP, guanosine triphosphate; ${ }^{*} \mathrm{p}<0.05 ; * * \mathrm{p}<0.01$. NS, not significant. 


\section{The relationship between the expression of $\mathrm{C5aR}$ and the prognosis of patients with gastric cancer}

The relationship between the expression of $\mathrm{C} 5 \mathrm{aR}$ and the prognosis of patients with GC was evaluated. $\mathrm{C} 5 \mathrm{aR}$ was predominantly expressed on the cell membrane and a score from zero to three was assigned according to the extent of staining (Figure 5A). Scores of 0, 1, 2 and 3 were given to $54(54.0 \%), 11(11.0 \%), 16(16.0 \%)$ and $19(19.0 \%)$ of the patient samples, respectively. High C5aR expression (score of $\geq 2$ ) was observed in 35 patients $(35.0 \%)$, which was significantly associated with invasion depth, stage and vascular invasion (Table 1).

The median follow-up period was 50.0 months. Among the 89 patients with stage I-III GC, the 5-year relapse-free survival rate for the patients with high C5aR-expression $(n=29,48.3 \%)$ was significantly worse than for those with low C5aR-expression $(\mathrm{n}=60$, $86.0 \% ; p=0.011$ ) (Figure 5B). From all 100 patients, the 5 -year overall survival of the patients with high C5aRexpression $(n=35,58.2 \%)$ was significantly worse than those with low C5aR-expression $(\mathrm{n}=65,88.5 \%$; $\mathrm{p}=$ 0.008 ) (Figure 5C). A univariate analysis for prognostic factors for overall survival in 100 patients with GC identified sex, age, tumor depth, lymph node metastasis, vascular and lymphatic infiltration, differentiation and C5aR-expression $(\mathrm{p} \leq 0.20)$. Multivariate analysis identified lymph node metastasis and C5aR-expression as prognostic factors for overall survival of the GC patients (Table 2).

\section{DISCUSSION}

Complement $\mathrm{C} 5 \mathrm{a}$ is a byproduct of the complement system via the classical, alternative and lectin pathways [11]. Recent studies indicate that C5aR (CD88) has a function in many different tissues, including the lung, heart, liver and kidneys [23-27], and that C5a is associated with many clinical conditions, including sepsis and rheumatoid arthritis [28-30]. We previously reported that $\mathrm{C} 5 \mathrm{a}$ promoted the mobility and invasive ability of cancer cells, such as cholangiocarcinoma cells $[15,25]$. Several papers have also reported relationships between C5aR expression and various cancers [16-18, $25]$. Thus, the research related to $\mathrm{C} 5 \mathrm{aR}$ in cancer and inflammation has recently received significant attention. In this study, we demonstrated that $\mathrm{C} 5 \mathrm{aR}$ expressing

A
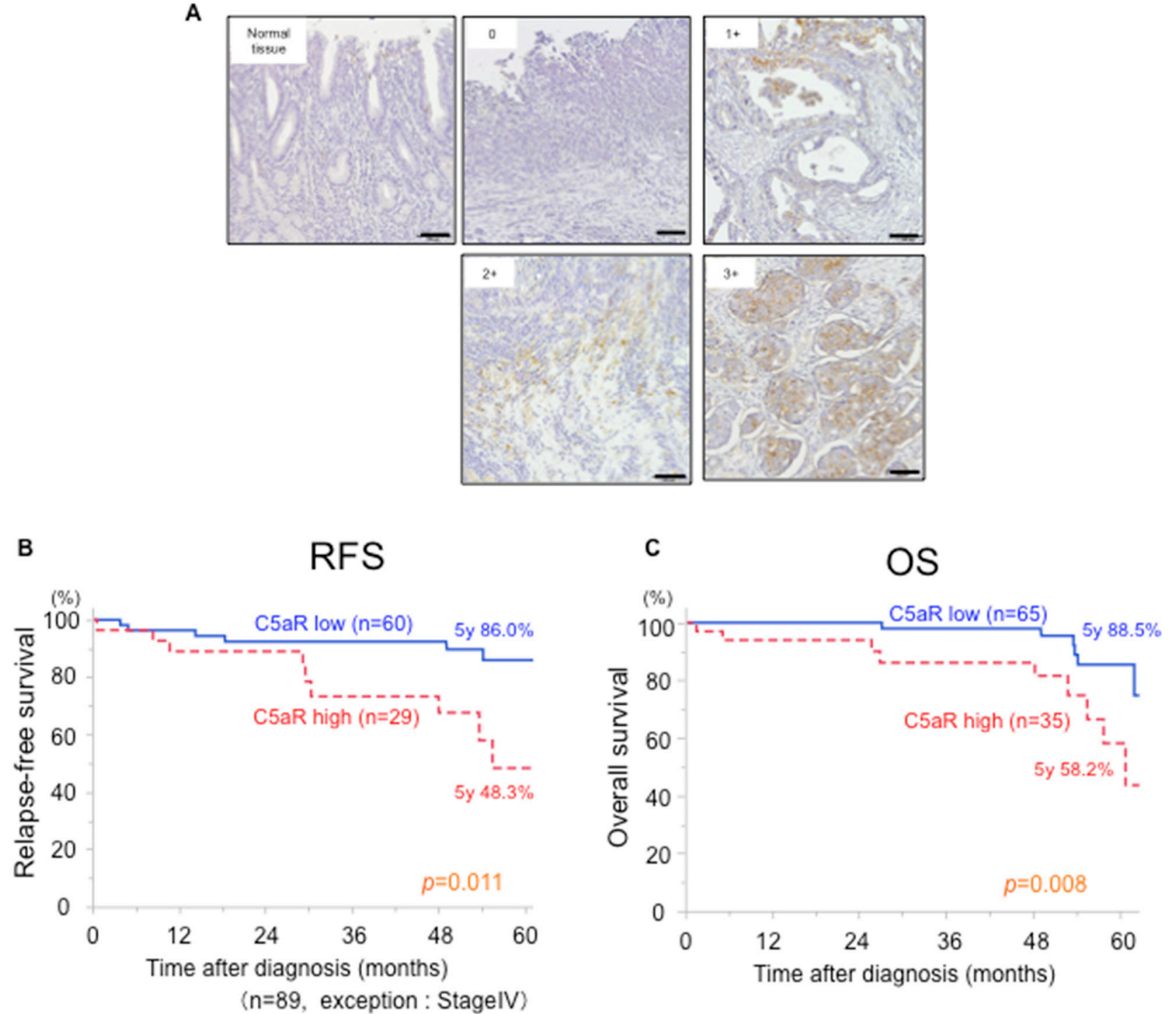

Figure 5: Relationship between C5aR expression and the prognosis of patients with gastric cancer. A., gastric cancer tissues were immunohistochemically stained with anti-C5aR antibody. One-hundred cases were scored from 0 to 3 according to the extent of C5aR staining in the cancer area. Scale bar: $100 \mu \mathrm{m}$. B., Relapse-free survival curves for 86 patients who underwent a gastrectomy for gastric cancer (excluding stage IV patients), which were stratified by low- and high-expression of C5aR. C., Overall survival curves for 100 patients who underwent gastrectomy for gastric cancer, which were stratified by low- and high-expression of C5aR. C5aR, C5a receptor; RFS, relapse-free survival; OS, overall survival. 
Table 1: Analysis of clinical factors associated with C5aR-expression from $\mathbf{1 0 0}$ patients with gastric cancer

\begin{tabular}{|c|c|c|c|}
\hline \multirow[t]{2}{*}{ Clinicopathological factors } & \multicolumn{2}{|c|}{ C5aR-expression } & \multirow[t]{2}{*}{$P$-value } \\
\hline & $\begin{array}{l}\text { Low group } \\
\quad(n=65)\end{array}$ & $\begin{array}{l}\text { High group } \\
\quad(\mathbf{n}=35)\end{array}$ & \\
\hline Mean age (years) \pm SD & $65.4 \pm 13.6$ & $65.8 \pm 11.0$ & 0.96 \\
\hline \multicolumn{4}{|l|}{ Sex } \\
\hline Male / Female & $40 / 25$ & $24 / 11$ & 0.48 \\
\hline \multicolumn{4}{|l|}{ Tumor location } \\
\hline Upper / Middle / Lower & $22 / 19 / 24$ & $9 / 12 / 14$ & 0.69 \\
\hline \multicolumn{4}{|l|}{ Differentiation } \\
\hline Intestinal / Diffuse & $30 / 35$ & $15 / 20$ & 0.75 \\
\hline \multicolumn{4}{|l|}{ Depth of invasion } \\
\hline pT1-2 & 50 & 18 & 0.009 \\
\hline pT3-4 & 15 & 17 & \\
\hline \multicolumn{4}{|l|}{ Lymph node metastasis } \\
\hline Negative & 47 & 20 & 0.12 \\
\hline Positive & 18 & 15 & \\
\hline \multicolumn{4}{|l|}{ pStage } \\
\hline I / II / III / IV & $47 / 8 / 5 / 5$ & $14 / 10 / 5 / 6$ & 0.02 \\
\hline \multicolumn{4}{|l|}{ Lymphatic invasion } \\
\hline Positive / Negative / UK & $40 / 24 / 1$ & $20 / 15 / 0$ & 0.60 \\
\hline \multicolumn{4}{|l|}{ Vascular invasion } \\
\hline Positive / Negative / UK & 37 / 27 / 1 & $12 / 23 / 0$ & 0.02 \\
\hline
\end{tabular}

UK: unknown

Sex, Tumor location, Differentiation, Depth of invasion, $\mathrm{pN}$ station, pStage, Lymphatic invasion, vascular invasion: $\chi^{2}$ test, Mean age: unpaid test

Table 2: Univariate and multivariate analysis of prognostic factors associated with the overall survival of patients with gastric cancer

\begin{tabular}{llcccc}
\hline Factors & \multicolumn{2}{c}{ Univariate analysis } & \multicolumn{3}{c}{ Multivariate analysis } \\
\cline { 2 - 5 } & $\mathbf{5 y O S}(\mathbf{\%})$ & $\boldsymbol{P}$ & HR & $\mathbf{9 5 \%}$ CI & $\boldsymbol{P}$ \\
\hline Sex (Male / Female) & $69.0 / 84.4$ & 0.09 & & & \\
Age $(<65$ / $\geq 65)$ & $79.6 / 74.6$ & 0.63 & & & \\
pT1-2 / pT3-4 & $87.9 / 52.8$ & 0.0002 & & & \\
Lymph node metastasis $-/+$ & $87.7 / 53.7$ & 0.0003 & 4.81 & & \\
Vascular invasion -/+ & $86.0 / 60.5$ & 0.009 & & & \\
Lymphatic invasion -/+ & $95.0 / 59.9$ & 0.003 & & & \\
Differentiation I/D & $84.1 / 69.4$ & 0.11 & & & \\
C5aR (Low / High) & $88.5 / 58.2$ & 0.004 & 3.13 & $1.12-9.44$ & \\
\hline
\end{tabular}

OS: overall survival, HR: hazard ration, CI: confidence interval, I: intestinal type, D: diffuse type 
GC cells have increased motility and invasiveness after stimulation with $\mathrm{C} 5 \mathrm{a}$. The C5a-C5aR signal enhanced the conversion of RhoA-GDP to RhoA-GTP and induced morphological changes to the GC cells. Moreover, examination of tumor specimens from GC patients who underwent a gastrectomy revealed that high C5aR-expression by the tumor is associated with a poor prognosis and increased invasiveness (Table 1, Figure 5). In addition, we reported that the gastric cancer patients with high-C5aR expression had higher incidence of liver metastasis than the patients with low-C5aR expression using another cohort $(13.3 \%$ vs $3.9 \%, \mathrm{P}=0.04$ ) [31]. These results suggested that $\mathrm{C} 5 \mathrm{aR}$ expressed on the membrane of GC cells may not only be a biomarker for prognosis but also an oncoprotein that promotes invasiveness by activating RhoA, resulting in liver metastasis and a poor prognosis (Figure 4C).

RhoA exists mostly in the cytosol in the GDPbound form (Rho-GDP). When the appropriate extra cellular factors stimulate cells by binding to G-protein coupled receptors coupled to the heterotrimeric G12/13 protein, Rho-GDP is converted to Rho-GTP by the catalytic effect of guanine nucleotide exchange factors, several of which are direct targets of the G12/13 alpha subunits [19-22, 32]. This study is the first to demonstrate that aberrantly expressed $\mathrm{C} 5 \mathrm{aR}$ promotes the conversion of RhoA-GDP to RhoA-GTP in cancer cells, which induces their cytoskeletal rearrangement and increases their invasive ability. RHOA encodes the small GTPase RhoA and regulates cancer cell contractility, cellular motility and metastasis of GC and other malignant tumors [5, 33-35]. Therefore, our clinical finding that high $\mathrm{C} 5 \mathrm{aR}$ expressing tumors are more invasive, which includes deeper invasion depth and a higher rate of vascular invasion, compared with those with low C5aR expression is consistent with the results of these previous studies and with our in vitro study.

C5a production is necessary to activate RhoA via $\mathrm{C} 5 \mathrm{aR}$. It has been reported that $\mathrm{C} 5 \mathrm{a}$ is generated by colon, ovarian and lung cancer cell without activation of the complement cascade $[16,17,36]$. In this study, GC cell lines also produced $\mathrm{C} 5 \mathrm{a}$ at concentration as low as $60 \mathrm{pg} / \mathrm{ml}$ (Supplementary Figure S3). Moreover, it was reported that $\mathrm{C} 5 \mathrm{a}$ was also released without activation of the complement cascade by cleavage of serum C5 by cancer cell membrane-bound proteases, thrombin or various proteases from phagocyte without activation of the complement cascade $[27,37,38]$. Therefore, C5a produced by both cancer cells and cleavage of serum C5 in the cancer microenvironment may continuously stimulate the conversion of RhoA-GDP to RhoA-GTP by stimulating $\mathrm{C} 5 \mathrm{aR}$, resulting in increased cancer cell motility and invasion.

C5a was reported to bind to not only C5aR, but also C5L2. In this study, we identified the expression of C5L2 in MKN1 and MKN7 cells (Supplementary Figure S1). It was difficult to evaluate the biological effect of C5L2 for gastric cancer cells, because siRNA used for C5aR knockdown also downregulated the C5L2 expression (Supplementary Figure S2B), It was suggested that C5L2 does not associated with cancer cell invasiveness via RhoA because C5L2 does not couple to G protein [12, 39, 40]. However, the effect of C5L2 on cancer cell biology cannot be ignored because stimulation of C5L2 with C5a or C5a-desArg activates extracellular signal-regulated kinase signaling via beta-arrestin [40]. Therefore, further study is needed to evaluate the association of C5L2 with cancer invasiveness.

In vivo, $\mathrm{C} 5 \mathrm{a}$ is rapidly changed into $\mathrm{C} 5 \mathrm{a}-\mathrm{des} \mathrm{Arg}$ by carboxypeptidase enzymes. C5a-desArg has a binding affinity with C5aR that is 10 - to 100 -fold lower than that of C5a [12]. Little has been reported about the association between C5a-desArg and cancer cells. However, C5adesArg induces Mac-1 induction in neutrophils via C5L2, resulting in an inflammatory reaction [41]. Because it was reported that Mac-1 promotes cancer liver metastasis in vivo [42], C5a-desArg may indirectly affect to cancer cell metastasis.

C5aR antagonist is an orally available C5aR inhibitor, which has been shown to competitively inhibit $\mathrm{C} 5 \mathrm{a}$ binding and $\mathrm{C} 5 \mathrm{a}$-induced functions in human neutrophils [43]. The C5aR antagonist has been used as a novel therapeutic drug in the clinical setting for various inflammatory diseases, such as rheumatoid arthritis [35, 44-46]. Here, we revealed that inhibition of the C5aR in GC cell lines using a C5aR antagonist suppressed the cell migration and invasion in vitro (Figure $3 \mathrm{C}-3 \mathrm{G}$ ). Although a further in vivo study is required to clarify the utility of the antagonist, C5aR may be a potential target for the treatment of patients with GC.

The tumor microenvironment plays an important role in cancer cell invasion and metastasis. C5a-C5aR signaling in premetastatic organs promoted the generation of regulatory $\mathrm{T}$ cells and suppressed T-cell responses, which was followed by an increase in distal metastasis [47]. Piao C et al. showed that C5a promoted the infiltration of macrophages, neutrophils and dendritic cells by stimulating C5aR, and increased the expression of antiinflammatory arginase 1 , transforming growth factor $\beta$ and interleukin 10 in the tumor microenvironment, promoting cancer metastasis [36]. Moreover, C5a generated in the tumor microenvironment promotes the production of vascular endothelial growth factor by endothelial cells, which promotes tumor angiogenesis [48, 49]. Thus, a C5aR antagonist might also suppress the invasion or metastasis of cancer cells by inhibiting C5a-C5aR signaling in cells of the tumor microenvironment.

In conclusion, we demonstrated that $\mathrm{C} 5 \mathrm{aR}$ stimulation with $\mathrm{C} 5 \mathrm{a}$ promotes the motility and invasion ability of GC cells by activating RhoA. Moreover, patients with high C5aR-expression were associated with 
a more invasive tumor and a poor prognosis. This study provides a novel insight into the mechanisms of GC cell invasion through the complement system and identifies a potential GC patient population that requires an advanced therapeutic strategy.

\section{MATERIALS AND METHODS}

\section{Cell lines}

We obtained the human GC cell lines MKN1 (established from adenosquamous carcinoma), MKN7 (established from well-differentiated tubular adenocarcinoma), NUGC3 and AGS (established from poorly differentiated tubular adenocarcinoma) from ATCC (Manassas, VA). Each cell line was grown in RPMI-1640 medium (Sigma-Aldrich, St. Louis, MO) supplemented with $10 \%$ decomplemented fetal bovine serum. The cells were maintained at $37^{\circ} \mathrm{C}$ and $5 \% \mathrm{CO}_{2}$.

\section{Reagents}

A rabbit polyclonal antibody against C5aR (CD88; sc-25774) was purchased from Santa Cruz Biotechnology (Texas, USA). An antibody against C5L2 was purchased from Atlas Antibodies (Stockholm, Sweden). A FITCconjugated mouse monoclonal antibody against C5aR (MCA2059FT) and a FITC-conjugated mouse polyclonal antibody against IgG2a (STAR133F) was purchased from Bio-Rad (California, USA). A mouse monoclonal antibody against C5aR (HM2094) was purchased from Hycult Biotech (PB Uden, Netherlands). Recombinant human Complement Component C5a (rC5a; 2037-C5-025) was obtained from R\&D Systems (Minneapolis, USA). The C5a receptor antagonist, W-54011 (sc-203863) was purchased from Santa Cruz Biotechnology. An ELISA kit was purchased from Thermo Scientific (Frederick, USA).

\section{SiRNA transfection}

C5aR-expression was transiently reduced using a predesigned Silencer Select siRNA directed against C5aR (Life Technologies Japan Ltd, Tokyo, Japan), and a non-targeting siRNA was used as a negative control. We transfected GC cells with the annealed siRNA for 48 hours using Lipofectamine RNAiMax (Thermo Fisher Scientific, Yokohama, Japan). The downregulation was confirmed by western blot analysis using a C5aR antibody.

\section{Western blot analysis}

Cultured cells were washed in PBS, lysed using RIPA Lysis and Extraction Buffer (Thermo Fisher Scientific, Yokohama, Japan) and added to a protease/ phosphatase inhibitor cocktail (Thermo Fisher Scientific, Yokohama, Japan). We subjected protein samples to sodium dodecyl sulfate polyacrylamide gel electrophoresis and transferred it to nitrocellulose membranes. The membranes were blocked with 5\% low-fat dry milk in Tris-Buffered saline and Tween (25 mM Tris [pH 7.4], 125 $\mathrm{mM} \mathrm{NaCl}$ and $0.4 \%$ Tween) and then incubated with the primary antibodies, including anti-C5aR and anti- $\beta$-actin antibodies, which were diluted in Tris-Buffered saline and Tween. The samples were incubated at $4{ }^{\circ} \mathrm{C}$ overnight. Signals were detected by incubation with rabbit secondary antibodies at room temperature for an hour using the ECL Detection System (GE Healthcare, Little Chalfont, UK). Peripheral blood mononuclear cells were used as positive control for C5aR and C5L2.

\section{Establishment of C5aR stably expressing NUGC 3 cells}

Human C5aR cDNA was purified according to a previously reported method [15]. Briefly, full-length human C5aR cDNA (1,053 base pairs) was amplified by PCR using a human macrophage cDNA library and the cDNA was subsequently subcloned into pENTR/DTOPO vectors (Thermo Fisher Scientific, Yokohama, Japan). After confirming the sequence, the cDNA was inserted into pCAG-IRES-puro vectors using the Gateway system (Invitrogen). The purified plasmid of C5aR was transfected into NUGC3 cells using Lipofectamine 3000 (Thermo Fisher Scientific, Yokohama, Japan). After transfection, the cells were cultured with selection medium supplemented with puromycin $(1 \mathrm{mg} / \mathrm{ml})$ for 2 weeks (NUGC3/C5aR). NUGC3 cells transfected with empty-pCAG-IRES-puro vectors were used as a control (NUGC3/mock).

\section{Growth assay}

MKN1 and MKN7 cells were inoculated in a 96well plate at $2.0 \times 10^{3}$ cells in $100 \mu \mathrm{l}$ per well and the plate was incubated overnight in a humidified incubator at $37^{\circ} \mathrm{C}$ with $5 \% \mathrm{CO}_{2}$. The medium was exchanged with medium containing the indicated concentrations of $\mathrm{rC} 5 \mathrm{a}$. Each well of the plate also received $10 \mu$ of the Cell Counting Kit8 solution (Dojindo Molecular Technologies, Kumamoto, Japan) at the indicated time. The absorbance was measured at $450 \mathrm{~nm}$ using a microplate reader after incubating the plate for 1.5 hours. The absorbance of each sample was measured in triplicate.

\section{Invasion assay}

BioCoat Matrigel invasion chambers were used (24well plates, $8 \mu \mathrm{m}$ pores; BD Biosciences, California, USA) according to the manufacture's protocol. MKN1, MKN7 and NUGC3/C5aR cells $\left(5.0 \times 10^{4}\right)$ were suspended in RPMI-1640 and seeded into the upper chamber. RPMI1640 supplemented with rC5a or a carrier solution (PBS) was placed in the lower chamber. The C5aR-antagonist (W-54011) or a carrier control (dimethyl sulfoxide) was 
added to the cell medium at the indicated concentrations 3 hours before the cells were seeded into the upper chamber. A C5aR-antagonist (W-54011) or carrier control (dimethyl sulfoxide) was also added to the medium of the upper chamber. The number of cells that migrated through the membrane were counted in five microscopic fields $(\times 20$ magnification) per membrane. The average was calculated from triplicate samples and statistical analyses were performed by two-tailed t-tests.

\section{Flow cytometry analysis}

The cells were adjusted to a concentration of $1.0 \times 10^{7}$ cells $/ \mathrm{ml}$ in PBS with $2 \%$ fetal bovine serum. Cell suspensions were incubated with a mouse monoclonal antiC5aR-FITC antibody (MCA2059FT) or a mouse polyclonal anti-IgG2a-FITC antibody (STAR133F) for 30 minutes at $4{ }^{\circ} \mathrm{C}$. Flow cytometry analysis was performed with a FACSVerse (BD Biosciences) and data were analyzed with FlowJo 3.3 software (Tree Star, San Carlos, CA).

\section{Real-time imaging of cell migration}

We performed real-time imaging of GC cells in 6-well plates. Each well was coated with $200 \mu \mathrm{l}$ of BD Matrigel (BD Biosciences, California, USA). NUGC3/ C5aR cells were plated and allowed to adhere for 12 hours. The 6-well plates were imaged with a KEYENCE BZ-X700 all-in-one fluorescence microscope equipped with a $\mathrm{CO}_{2}$ and temperature controlled chamber and time-lapse tracking system (KEYENCE, Osaka, Japan). Phase contrast images were taken every 10 minutes for 24 hours and converted to movie files using a BZ-X Analyzer (KEYENCE). We analyzed the movies for cell migration with the video editing analysis software VW-H2MA (KEYENCE) and subsequently processed the tracking data with Microsoft Excel 2010 (Microsoft, Redmond, WA) to create xy coordinate plots and distance measurements.

\section{Immunofluorescence analysis}

Cells $\left(5.0 \times 10^{4}\right)$ were seeded on a $35 \mathrm{~mm}$ glassbottomed dish (Matsunami Glass Ind., Kishiwada, Japan) and allowed to grow for 24 hours. After 6 hours of serum starvation, the cells were stimulated with $10 \mathrm{nM}$ of $\mathrm{rC} 5 \mathrm{a}$ for the stated time periods. The cells were then fixed in 4\% paraformaldehyde for 15 minutes, permeabilized in $0.1 \%$ Triton X-100 for 5 minutes, incubated with $5 \mathrm{U} / \mathrm{ml}$ Alexa 488-phalloidin (Invitrogen Life Technologies) for 40 minutes and then washed with PBS. Cell nuclei were counterstained with Hoechst 33258 (Life Technologies, Tokyo, Japan) for 15 minutes. Images were obtained and processed with a FluoView 1200 laser scanning confocal microscope (Olympus, Tokyo, Japan).

\section{Rho GTPase activity assays}

RhoA activity was evaluated using a colorimetric RhoA activity assay (Cytoskeleton, Inc., Denver, USA) according to the manufacturer's instructions. Briefly, cells were lysed using an ice cold lysis buffer and the protein concentration was equalized. We applied $25 \mu \mathrm{l}$ of equalized cell extract on the kit provided 96-well plate and placed the plate on an orbital shaker at $400 \mathrm{rpm}$ at $4{ }^{\circ} \mathrm{C}$ for 30 minutes. The plate was subsequently incubated at room temperature in Antigen Presenting Buffer for 2 minutes, anti-RhoA primary antibody for 45 minutes, the secondary antibody for 45 minutes, and horseradish peroxidase detection reagent for 15 minutes. The absorbance of each sample was measured in triplicate at $490 \mathrm{~nm}$ and recorded using a microplate spectrophotometer.

\section{ELISAs of cultured medium supernatant}

The concentration of C5a was evaluated using an enzyme-linked immunosorbent assay (Thermo Scientific, Frederick, USA) according to the manufacturer's instructions. Briefly, medium of the indicated cells were taken, when the cells were $80-90 \%$ confluent. Cell supernatant $(100 \mu \mathrm{L})$ was added to the wells and incubated for 2.5 hours at room temperature with gentle shaking. Each well received $100 \mu \mathrm{L}$ of biotinylated antibody and the place was incubated for 1 hour at room temperature with gentle shaking. Streptavidin-HRP solution $(100 \mu \mathrm{L})$ was added to each well and the place was incubated for 45 minutes at room temperature with gentle shaking. Each well then received $100 \mu \mathrm{L}$ of TMB Substrate and the place was incubated for 30 minutes at room temperature in the dark with gentle shaking. The absorbance of each sample was measured in triplicate at $450 \mathrm{~nm}$ and recorded using a microplate spectrophotometer.

\section{Patients}

The surgical GC specimens were obtained from 100 patients who underwent gastrectomy in Kumamoto University Hospital (Kumamoto, Japan) from January 2010 to December 2011. A follow-up, including an upper gastrointestinal endoscopy, computerized tomography and blood examination, was conducted every 3 months for less than 2 years after surgery. We performed the follow-up every other year from a half year until 5 years after surgery. Diagnosis of GC, invasion depth, vascular and lymphatic invasion, lymph node metastasis and differentiation were confirmed by histopathological examination of the resected specimens. Written informed consent was obtained from each subject, approval was acquired from the institutional ethics committee (No. 1051) and the study was performed in accordance with the Helsinki Declaration of 1975. Tumor staging followed the American Joint Committee on Cancer Staging Manual (7th edition) $[50]$. 


\section{Immunohistochemistry}

Sections $4 \mu \mathrm{m}$ thick were pretreated with $0.3 \%$ $\mathrm{H}_{2} \mathrm{O}_{2}$ in methanol for 30 minutes after deparaffinization. Sections were then incubated with diluted primary antibody (C5aR) at $4{ }^{\circ} \mathrm{C}$ overnight and detection was performed with an EnVision+ detection system (Daka, Tokyo, Japan). Nuclei were counterstained with hematoxylin. All staining was independently scored by two blinded pathologists. For each tissue section, five high-power fields $(\times 100)$ were randomly selected and the average stained area per each power field were calculated. The average percentage of the stained area was scored as 0 for $0 \%, 1$ for $1-25 \%, 2$ for $26-50 \%$ and 3 for $51-100 \%$. A total C $5 \mathrm{aR}$ expression score of $\geq 2$ was classified as high C5a expression.

\section{Statistical analysis}

All statistical analyses were carried out using JMP ${ }^{\circledR}$ 11 (SAS Institute Inc., Cary, NC, USA). Continuous variables were compared using a Student's t-test. Categorical variables were compared using the chi-square test. Survival time was defined from the date of diagnosis until the date of death; overall survival and relapse-free survival were calculated using the Kaplan-Meier method and differences in survival between the groups were analyzed using a log-rank test. Variables that exhibited $P$ value of $<0.20$ on univariate analysis for risk factors affecting OS were subjected to multivariate analysis using Cox proportional hazard model. All variables associated with prognosis were candidates using a stepwise backward elimination procedure with a threshold $P<0.05$. $\mathrm{p}<0.05$ was considered significant.

\section{ACKNOWLEDGMENTS}

This work was supported in part by the Japan Society for the Promotion of Science (JSPS) Grant-in-Aid for Scientific Research, (grant number 25462099).

\section{CONFLICTS OF INTEREST}

No conflict of interest exists.

\section{REFERENCES}

1. Cancer Genome Atlas Research, N. Comprehensive molecular characterization of gastric adenocarcinoma. Nature. 2014; 513: 202-9. doi: 10.1038/nature13480.

2. Yan, W, Qian L, Chen J, Chen W, Shen B. Comparison of Prognostic MicroRNA Biomarkers in Blood and Tissues for Gastric Cancer. J Cancer. 2016; 7: 95-106. doi: 10.7150/ jca.13340.

3. Yasui, W, Oue N, Aung PP, Matsumura S, Shutoh M, Nakayama H. Molecular-pathological prognostic factors of gastric cancer: a review. Gastric Cancer. 2005; 8: 86-94. doi: 10.1007/s10120-005-0320-0.

4. Bang, YJ, Van Cutsem E, Feyereislova A, Chung HC, Shen L, Sawaki A, Lordick F, Ohtsu A, Omuro Y, Satoh T, Aprile G, Kulikov E, Hill J, et al. Trastuzumab in combination with chemotherapy versus chemotherapy alone for treatment of HER2-positive advanced gastric or gastro-oesophageal junction cancer (ToGA): a phase 3, open-label, randomised controlled trial. Lancet. 2010; 376: 687-97. doi: 10.1016/ s0140-6736(10)61121-x.

5. Ushiku, T, Ishikawa S, Kakiuchi M, Tanaka A, Katoh H, Aburatani H, Lauwers GY, Fukayama M. RHOA mutation in diffuse-type gastric cancer: a comparative clinicopathology analysis of 87 cases. Gastric Cancer. 2015. doi: 10.1007/s10120-015-0493-0.

6. Ishimoto, T, Nagano O, Yae T, Tamada M, Motohara T, Oshima H, Oshima M, Ikeda T, Asaba R, Yagi H, Masuko $\mathrm{T}$, Shimizu T, Ishikawa T, et al. CD44 variant regulates redox status in cancer cells by stabilizing the $\mathrm{xCT}$ subunit of system xc(-) and thereby promotes tumor growth. Cancer Cell. 2011; 19: 387-400. doi: 10.1016/j.ccr.2011.01.038.

7. Wada, T, Ishimoto T, Seishima R, Tsuchihashi K, Yoshikawa M, Oshima H, Oshima M, Masuko T, Wright NA, Furuhashi S, Hirashima K, Baba H, Kitagawa Y, et al. Functional role of CD44v-xCT system in the development of spasmolytic polypeptide-expressing metaplasia. Cancer Sci. 2013; 104: 1323-9. doi: 10.1111/cas.12236.

8. Espelin, CW, Leonard SC, Geretti E, Wickham TJ, Hendriks BS. Dual HER2 targeting with trastuzumab and liposomeencapsulated doxorubicin (MM-302) demonstrates synergistic antitumor activity in breast and gastric cancer. Cancer Res. 2016. doi: 10.1158/0008-5472.CAN-15-1518.

9. Oue, N, Sentani K, Sakamoto N, Yasui W. Clinicopathologic and molecular characteristics of gastric cancer showing gastric and intestinal mucin phenotype. Cancer Sci. 2015; 106: 951-8. doi: 10.1111/cas.12706.

10. Tanner, M, Hollmen M, Junttila TT, Kapanen AI, Tommola S, Soini Y, Helin H, Salo J, Joensuu H, Sihvo E, Elenius K, Isola J. Amplification of HER-2 in gastric carcinoma: association with Topoisomerase IIalpha gene amplification, intestinal type, poor prognosis and sensitivity to trastuzumab. Ann Oncol. 2005; 16: 273-8. doi: 10.1093/ annonc/mdi064.

11. Huber-Lang, MS, Sarma JV, McGuire SR, Lu KT, Padgaonkar VA, Younkin EM, Guo RF, Weber CH, Zuiderweg ER, Zetoune FS, Ward PA. Structure-function relationships of human C5a and C5aR. J Immunol. 2003; 170: 6115-24.

12. Klos, A, Wende E, Wareham KJ, Monk PN. International Union of Basic and Clinical Pharmacology. [corrected]. LXXXVII. Complement peptide C5a, C4a, and C3a receptors. Pharmacol Rev. 2013; 65: 500-43.

13. Gerard, NP, Gerard C. The chemotactic receptor for human C5a anaphylatoxin. Nature. 1991; 349: 614-7. doi: 10.1038/349614a0. 
14. Smedly, LA, Tonnesen MG, Sandhaus RA, Haslett C, Guthrie LA, Johnston RB, Jr., Henson PM, Worthen GS. Neutrophil-mediated injury to endothelial cells. Enhancement by endotoxin and essential role of neutrophil elastase. J Clin Invest. 1986; 77: 1233-43. doi: 10.1172/ JCI112426.

15. Nitta, H, Wada Y, Kawano Y, Murakami Y, Irie A, Taniguchi K, Kikuchi K, Yamada G, Suzuki K, Honda J, WilsonMorifuji M, Araki N, Eto M, et al. Enhancement of human cancer cell motility and invasiveness by anaphylatoxin C5a via aberrantly expressed C5a receptor (CD88). Clin Cancer Res. 2013; 19: 2004-13. doi: 10.1158/1078-0432. CCR-12-1204.

16. Gu, J, Ding JY, Lu CL, Lin ZW, Chu YW, Zhao GY, Guo J, Ge D. Overexpression of CD88 predicts poor prognosis in non-small-cell lung cancer. Lung Cancer. 2013; 81: 259-65. doi: 10.1016/j.lungcan.2013.04.020.

17. Cho MS, Vasquez HG, Rupaimoole R, Pradeep S, Wu S, Zand B, Han HD, Rodriguez-Aguayo C, Bottsford-Miller J, Huang J, Miyake T, Choi HJ, Dalton HJ, et al. Autocrine effects of tumor-derived complement. Cell Rep. 2014; 6: 1085-95. doi: 10.1016/j.celrep.2014.02.014.

18. Imamura, T, Yamamoto-Ibusuki M, Sueta A, Kubo T, Irie A, Kikuchi K, Kariu T, Iwase H. Influence of the C5a$\mathrm{C} 5 \mathrm{a}$ receptor system on breast cancer progression and patient prognosis. Breast Cancer. 2015. doi: 10.1007/ s12282-015-0654-3.

19. Fukata, M, Kaibuchi K. Rho-family GTPases in cadherinmediated cell-cell adhesion. Nat Rev Mol Cell Biol. 2001; 2: 887-97. doi: 10.1038/35103068.

20. Goggs, R, Williams CM, Mellor H, Poole AW. Platelet Rho GTPases-a focus on novel players, roles and relationships. Biochem J. 2015; 466: 431-42. doi: 10.1042/BJ20141404.

21. Halayko, AJ, Solway J. Molecular mechanisms of phenotypic plasticity in smooth muscle cells. J Appl Physiol (1985). 2001; 90: 358-68.

22. Chrzanowska-Wodnicka, M, Burridge K. Rho-stimulated contractility drives the formation of stress fibers and focal adhesions. J Cell Biol. 1996; 133: 1403-15.

23. Riedemann, NC, Guo RF, Sarma VJ, Laudes IJ, HuberLang M, Warner RL, Albrecht EA, Speyer CL, Ward PA. Expression and function of the $\mathrm{C} 5$ a receptor in rat alveolar epithelial cells. J Immunol. 2002; 168: 1919-25.

24. Zhang, JX, Zha WS, Ye LP, Wang F, Wang H, Shen T, Wu $\mathrm{CH}, \mathrm{Zhu} \mathrm{QX}$. Complement C5a-C5aR interaction enhances MAPK signaling pathway activities to mediate renal injury in trichloroethylene sensitized $\mathrm{BALB} / \mathrm{c}$ mice. J Appl Toxicol. 2016; 36: 271-84. doi: 10.1002/jat.3179.

25. Maeda, Y, Kawano Y, Wada Y, Yatsuda J, Motoshima T, Murakami Y, Kikuchi K, Imamura T, Eto M. C5aR is frequently expressed in metastatic renal cell carcinoma and plays a crucial role in cell invasion via the ERK and PI3 kinase pathways. Oncol Rep. 2015; 33: 1844-50. doi: 10.3892/or.2015.3800.
26. Allen-Gipson, DS, Floreani AA, Heires AJ, Sanderson SD, MacDonald RG, Wyatt TA. Cigarette smoke extract increases $\mathrm{C} 5 \mathrm{a}$ receptor expression in human bronchial epithelial cells. J Pharmacol Exp Ther. 2005; 314: 476-82. doi: 10.1124/jpet.104.079822.

27. Kurihara, R, Yamaoka K, Sawamukai N, Shimajiri S, Oshita K, Yukawa S, Tokunaga M, Iwata S, Saito K, Chiba K, Tanaka Y. C5a promotes migration, proliferation, and vessel formation in endothelial cells. Inflamm Res. 2010; 59: 65966. doi: 10.1007/s00011-010-0178-4.

28. Czermak, BJ, Sarma V, Pierson CL, Warner RL, HuberLang M, Bless NM, Schmal H, Friedl HP, Ward PA. Protective effects of C5a blockade in sepsis. Nat Med. 1999; 5: 788-92. doi: 10.1038/10512.

29. Jose, PJ, Moss IK, Maini RN, Williams TJ. Measurement of the chemotactic complement fragment $\mathrm{C} 5 \mathrm{a}$ in rheumatoid synovial fluids by radioimmunoassay: role of $\mathrm{C} 5 \mathrm{a}$ in the acute inflammatory phase. Ann Rheum Dis. 1990; 49: $747-52$

30. Atkinson, SM, Nansen A, Usher PA, Sondergaard BC, Mackay CR, Friedrichsen B, Chang CC, Tang R, Skov $\mathrm{S}$, Haase C, Hornum L. Treatment with anti-C5aR $\mathrm{mAb}$ leads to early-onset clinical and mechanistic effects in the murine delayed-type hypersensitivity arthritis model. Autoimmunity. 2015; 48: 460-70. doi: 10.3109/08916934.2015.1031888.

31. Nitta, H, Shimose T, Emi Y, Imamura T, Ohnishi K, Kusumoto T, Yamamoto M, Fukuzawa K, Takahashi I, Higashi H, Tsuji A, Akagi Y, Oki E, et al. Expression of the anaphylatoxin $\mathrm{C} 5 \mathrm{a}$ receptor in gastric cancer: implications for vascular invasion and patient outcomes. Med Oncol. 2016; 33: 118. doi: 10.1007/s12032-016-0834-9.

32. Walsh, CT, Stupack D, Brown JH. G protein-coupled receptors go extracellular: RhoA integrates the integrins. Mol Interv. 2008; 8: 165-73. doi: 10.1124/mi.8.4.8.

33. Kakiuchi, M, Nishizawa T, Ueda H, Gotoh K, Tanaka A, Hayashi A, Yamamoto S, Tatsuno K, Katoh H, Watanabe Y, Ichimura T, Ushiku T, Funahashi S, et al. Recurrent gainof-function mutations of RHOA in diffuse-type gastric carcinoma. Nat Genet. 2014; 46: 583-7. doi: 10.1038/ ng.2984.

34. Wang, K, Yuen ST, Xu J, Lee SP, Yan HH, Shi ST, Siu HC, Deng S, Chu KM, Law S, Chan KH, Chan AS, Tsui WY, et al. Whole-genome sequencing and comprehensive molecular profiling identify new driver mutations in gastric cancer. Nat Genet. 2014; 46: 573-82. doi: 10.1038/ng.2983.

35. Yoon, C, Cho SJ, Aksoy BA, Park DJ, Schultz N, Ryeom SW, Yoon SS. Chemotherapy Resistance in Diffuse-Type Gastric Adenocarcinoma Is Mediated by RhoA Activation in Cancer Stem-Like Cells. Clin Cancer Res. 2015. doi: 10.1158/1078-0432.CCR-15-1356.

36. Piao, C, Cai L, Qiu S, Jia L, Song W, Du J. Complement 5a Enhances Hepatic Metastases of Colon Cancer via Monocyte Chemoattractant Protein-1-mediated 
Inflammatory Cell Infiltration. J Biol Chem. 2015; 290: 10667-76. doi: 10.1074/jbc.M114.612622.

37. Huber-Lang, M, Younkin EM, Sarma JV, Riedemann $\mathrm{N}$, McGuire SR, Lu KT, Kunkel R, Younger JG, Zetoune FS, Ward PA. Generation of C5a by phagocytic cells. Am J Pathol. 2002; 161: 1849-59. doi: 10.1016/ S0002-9440(10)64461-6.

38. Huber-Lang, M, Sarma JV, Zetoune FS, Rittirsch D, Neff TA, McGuire SR, Lambris JD, Warner RL, Flierl MA, Hoesel LM, Gebhard F, Younger JG, Drouin SM, et al. Generation of $\mathrm{C} 5 \mathrm{a}$ in the absence of $\mathrm{C} 3$ : a new complement activation pathway. Nat Med. 2006; 12: 682-7. doi: $10.1038 / \mathrm{nm} 1419$.

39. Van Lith, LH, Oosterom J, Van Elsas A, Zaman GJ. C5astimulated recruitment of beta-arrestin2 to the nonsignaling 7-transmembrane decoy receptor C5L2. J Biomol Screen. 2009; 14: 1067-75. doi: 10.1177/1087057109341407.

40. Hsu, WC, Yang FC, Lin CH, Hsieh SL, Chen NJ. C5L2 is required for C5a-triggered receptor internalization and ERK signaling. Cell Signal. 2014; 26: 1409-19. doi: 10.1016/j. cellsig.2014.02.021.

41. Chen, NJ, Mirtsos C, Suh D, Lu YC, Lin WJ, McKerlie C, Lee T, Baribault H, Tian H, Yeh WC. C5L2 is critical for the biological activities of the anaphylatoxins $\mathrm{C} 5 \mathrm{a}$ and $\mathrm{C} 3 \mathrm{a}$. Nature. 2007; 446: 203-7. doi: 10.1038/nature05559.

42. Spicer, JD, McDonald B, Cools-Lartigue JJ, Chow SC, Giannias B, Kubes P, Ferri LE. Neutrophils promote liver metastasis via Mac-1-mediated interactions with circulating tumor cells. Cancer Res. 2012; 72: 3919-27. doi: 10.1158/0008-5472.CAN-11-2393.

43. Sumichika, H, Sakata K, Sato N, Takeshita S, Ishibuchi S, Nakamura M, Kamahori T, Ehara S, Itoh K, Ohtsuka T, Ohbora T, Mishina T, Komatsu H, et al. Identification of a potent and orally active non-peptide C5a receptor antagonist. J Biol Chem. 2002; 277: 49403-7. doi: 10.1074/ jbc.M209672200.

44. Sumichika, H. C5a receptor antagonists for the treatment of inflammation. Curr Opin Investig Drugs. 2004; 5: 505-10.

45. Vergunst, CE, Gerlag DM, Dinant H, Schulz L, Vinkenoog M, Smeets TJ, Sanders ME, Reedquist KA, Tak PP. Blocking the receptor for C5a in patients with rheumatoid arthritis does not reduce synovial inflammation. Rheumatology (Oxford). 2007; 46: 1773-8. doi: 10.1093/ rheumatology/kem222.

46. Nitta, H, Murakami Y, Wada Y, Eto M, Baba H, Imamura T. Cancer cells release anaphylatoxin $\mathrm{C} 5 \mathrm{a}$ from $\mathrm{C} 5$ by serine protease to enhance invasiveness. Oncol Rep. 2014; 32: 1715-9. doi: 10.3892/or.2014.3341.

47. Vadrevu, SK, Chintala NK, Sharma SK, Sharma P, Cleveland C, Riediger L, Manne S, Fairlie DP, Gorczyca W, Almanza O, Karbowniczek M, Markiewski MM. Complement c5a receptor facilitates cancer metastasis by altering $\mathrm{T}$-cell responses in the metastatic niche. Cancer Res. 2014; 74: 3454-65. doi: 10.1158/0008-5472. CAN-14-0157.

48. Nunez-Cruz, S, Gimotty PA, Guerra MW, Connolly DC, Wu YQ, DeAngelis RA, Lambris JD, Coukos G, Scholler N. Genetic and pharmacologic inhibition of complement impairs endothelial cell function and ablates ovarian cancer neovascularization. Neoplasia. 2012; 14: 994-1004.

49. Eatock, MM, Schatzlein A, Kaye SB. Tumour vasculature as a target for anticancer therapy. Cancer Treat Rev. 2000; 26: 191-204. doi: 10.1053/ctrv.1999.0158.

50. Washington, K. 7th edition of the AJCC cancer staging manual: stomach. Ann Surg Oncol. 2010; 17: 3077-9. doi: 10.1245/s10434-010-1362-z. 